\title{
Hidden mediator roles of university spin-offs in Triple Helix networks
}

\author{
Marina van Geenhuizen ${ }^{1}$, Qing Ye ${ }^{2}$ and Mozhdeh Taheri ${ }^{1^{*}}$
}

\author{
* Correspondence: \\ m.taheri@tudelft.nl \\ ${ }^{1}$ Faculty of Technology, Policy and \\ Management, Delft University of \\ Technology, Jaffalaan 5, 2628 BX \\ Delft, The Netherlands \\ Full list of author information is \\ available at the end of the article
}

\begin{abstract}
University spin-off firms contribute to bringing knowledge created at university to market. The networks these firms employ with other Triple Helix actors serve as not only getting access to resources but also shaping processes of collective learning in transforming the knowledge most adequately. In addition, spin-offs may affect the networks and behavior of network participants. While the first role has received large attention, collective learning and transforming networks and network partners have not. The paper addresses a key requirement in this setting, namely diversity in networks. We use a database of 105 young university spin-off firms and measure the socio-economic networks. A share of around 25 to $35 \%$ of the firms tends to have an important potential mediator role, as they employ three to five different partners, connect with large firms as well as governments (outside the university), and have inserted a majority of strangers (outsiders) in their network. In the next step, to better understand partner diversity, we assess a simplified model. The level of innovativeness is found to be an important driver of diversity, with pre-start working experience (domains) and multidisciplinary education as important enabling factors. In exploring actual mediator roles using two case studies, we observe that Triple Helix actors are most diverse and tightly connected in testing activities in practice (pilots) enabling transformation of networks and network partners. The paper concludes with a summary, policy relevance, and future research paths.
\end{abstract}

Keywords: Spin-off firms, Networks, Triple Helix networks, Diversity, Mediator role

\section{Springer}

(C) 2016 van Geenhuizen et al. Open Access This article is distributed under the terms of the Creative Commons Attribution 4.0 International License (http://creativecommons.org/licenses/by/4.0/), which permits unrestricted use, distribution, and reproduction in any medium, provided you give appropriate credit to the original author(s) and the source, provide a link to the Creative Commons license, and indicate if changes were made. 


\section{Resumen}

Empresas spin-off universitarias contribuyen a llevar el conocimiento creado de la universidad al mercado. Las redes de estas empresas emplean con otros actores de la Triple Hélice no sólo sirven para obtener acceso a recursos, sino también para dar forma a procesos de aprendizaje colectivo. Además, empresas spin-off pueden afectar a las redes y el comportamiento de los participantes de la red. Sin embargo, el aprendizaje colectivo, la transformación de las redes, y la conformación de socios y su comportamiento, no han recibido mucha atención en la literatura.

Este artículo aborda un requisito clave en este contexto; a saber, la diversidad en las redes. Utilizamos una base de datos de 105 empresas spin-off jóvenes y analizamos la composición socioeconómica de sus redes. Una proporción del 25 al 35 por ciento de las firmas tienen un importante papel potencial mediador, ya que emplean de tres a cinco socios, se conectan con empresas grandes, y con gobiernos (fuera de la universidad) y además permiten agentes foráneos en su red.

Para entender mejor la diversidad de socios, evaluamos un modelo simplificado. El nivel de innovación resulta ser un motor importante de la diversidad, con el trabajo previo al inicio de la experiencia (dominios) y la educación multidisciplinar como factores de apoyo importantes. En la exploración de las funciones mediadoras reales, observamos que los actores de la Triple Hélice son más diversos y bien conectados a pruebas piloto que permiten la transformación de las redes y los socios de la red. El artículo concluye con implicaciones para políticas públicas y futuras líneas de investigación.

\section{Résumé}

Les entreprises spin-offs d'université contribuent à acheminer vers le marché le savoir créé par les universités. Les réseaux que ces entreprises utilisent en relation avec d'autres acteurs de la Triple Hélice servent non seulement à accéder aux ressources mais également à façonner les processus d'apprentissage collectif par la transformation la plus adéquate du savoir. En outre, les spin-offs peuvent affecter les réseaux ainsi que le comportement de leurs acteurs. Si le premier rôle a beaucoup retenu l'attention, ce n'est pas le cas de l'apprentissage collectif et des réseaux de transformation et partenaires de réseaux. Cet article répond à une exigence dans ce cadre, notamment la diversité dans les réseaux. Nous avons utilisé une base de données de 105 jeunes spin-offs d'université et mesuré les réseaux socioéconomiques. Environ 25 à $35 \%$ des entreprises ont tendance à avoir un rôle important de médiateur potentiel, étant donné qu'ils emploient trois à cinq partenaires différents, sont connectés aux grandes entreprises aussi bien qu'aux services publics (en dehors de l'université) et comptent dans leurs réseaux une majorité d'étrangers. Ensuite, en vue de mieux comprendre la diversité des partenaires, nous avons évalué un modèle simplifié. Le niveau d'innovation s'est révélé un important moteur de diversité avec une expérience initiale de travail (domaine) et l'éducation multidisciplinaire comme un important facteur favorable. En explorant les rôles réels de médiateur à partir de deux études de cas, nous avons observé que les acteurs de la Triple Hélice sont assez diversifiés et étroitement connexes dans la pratique des activités de test (pilotes) permettant la transformation des réseaux et des partenaires de réseaux. L'article se conclut avec un résumé, la pertinence de la politique et des pistes pour les recherches futures. 
摘 要

大学衍生公司有助于把在大学里创造的知识推向市场。它们与其它三螺旋主体 之间形成的网络不仅服务于获得资源，而且也在最充分地转化知识中促进集体学 习过程。此外，大学衍生公司也可能会影响网络和网络参与者的行为。虽然主体 已经受到很大关注,但集体学习、网络转变和网络合作伙伴都没有(得到应有的关 注)。本文解决了在这个设置中的一个关键要求,即网络多样性。我们利用 105 个 年轻的大学衍生公司的数据来测量社会经济网络。其中约有 $25 \%$ 至35\%的公司具 有重要的潜在中介作用 ——当它们拥有三至五个不同的合作伙伴并且与大公司 及政府联系时(除大学外), 并且在它们的网络中陌生人(外来人)已占大多数时。下 一步, 为了更好地理解合作伙伴的多样性, 我们探讨了一个简化模型。我们发现创 新水平是多样性的重要驱动, 启动前的工作经验(领域)和多学科的教育背景成为 重要有利因素。在利用两个案例探索实际的中介作用的过程中，我们观察到在实 践中三螺旋主体的最大多元化和在试验活动中的紧密联系使网络转变和网络合 作伙伴关系成为可能。本文就政策相关性和未来的研究路径得出总结性结论。

\section{Аннотация}

Университетские спин-офф компании вносят вклад в выведение знаний из университета на рынок. Экосистемы, в которых данные фирмы взаимодействуют с другими участниками Тройной спирали, позволяют не только получить доступ К необходимым ресурсам, но и обеспечить протекание процесса коллективного обучения путем трансформации знаний наиболее оптимальным образом. Кроме того, спин-офф'ы могут оказывать влияние на взаимодействие и поведение всех участников сети. В то время как первое из упомянутых направлений является достаточно изученным, коллективное обучение и трансформация в сетях освещены в гораздо меньшей степени. Настоящая статья посвящена ключевым требованиям к ним, а именно к разнообразию в сетях. Мы использовали базу данных, состоящую из 105 молодых спин-офф компаний, на примере которых исследовали социоэкономическое взаимодействие. Примерно 25-35 \% из них потенциально могли оказать значительное влияние на экосистему, поскольку взаимодействовали с тремя-пятью партнерами, имели деловые связи с крупными фирмами, а также правительством (вне университета), и вовлекли наибольшее число внешних участников в сеть. Далее для лучшего понимания результатов, мы провели оценку упрощенной модели. Так, было выявлено, что уровень инновационности является важным драйвером в поддержании разнообразия; не менее важны опыт работы и наличие мультидисциплинарного образования. Изучая роли участников на примере двух компаний, мы обнаружили, что акторы Тройной спирали являются наиболее разнообразными и тесно вовлеченными в практические (пилотные) проекты, обеспечивая трансформацию сети и ее участников. В заключении статьи приведены выводы, отмечено соответствие затронутой темы политическим инициативам, а также освещены дальнейшие направления исследования. 


\section{Resumo}

Empresas Spin-off universitárias contribuem em trazer conhecimentos criados na universidade para o mercado. As redes nas quais essas empresas participam com outros atores da Hélice Tríplice servem não somente para ter acesso a recursos, mas também para modelar processos de aprendizagem coletiva que em transformar o conhecimento de forma mais adequada. Além disso, spin-offs podem afetar as redes e o comportamento dos participantes da rede. Enquanto o primeiro papel tem recebido grande atenção, o mesmo não acontece com o aprendizado coletivo e a transformação das redes e dos parceiros da rede. $\mathrm{O}$ artigo aborda um requisito chave nesse cenário como a diversificação das redes. Utilizamos uma base de dados de 105 empresas jovens spin-off universitárias e medimos as redes socioeconômicas. Uma parcela de cerca de 25 a 30 por cento das empresas por reunirem de 3 a 5 parceiros diferentes tendem a ter um papel importante como mediador potencial, conectando-se com grandes empresas, bem como os governos (fora da universidade) e inserem a maioria dos estrangeiros (outsiders) na sua rede. Na etapa seguinte, para entender melhor a diversidade de parcerias, avaliamos um modelo simplificado.

O nível de inovatividade é um importante motor da diversidade, onde a experiência prévia em trabalhos (domínios) e a educação multidisciplinar são fatores favoráveis importantes.

Ao explorar os papéis de mediadores reais, usando os dois estudos de caso, observamos que os atores da Hélice Tríplice são mais diversos e firmemente ligados em atividades de teste na prática (pilotos) permitindo a transformação das redes e parceiros da rede. $\mathrm{O}$ artigo conclui com um sumário, a relevância política e os caminhos futuros de pesquisa.

\section{Multilingual abstract}

Please see Additional file 1 for translation of the abstract into Arabic.

\section{Introduction}

The future of many countries today is seen as dependent upon opportunities of science, engineering, and technology. This is specifically true in the European Union, where these assets are serving to solve the grand societal challenges and increasing competitiveness of the European economy (EC 2014). University spin-offs (USOs), the focal firms in this study, are an important part of this attention when it comes to economic and social use of knowledge created at universities and other higher educational institutes. Though intermediation is certainly not the primary aim of these firms, they may take on such a role in connecting different Triple Helix partners and improving knowledge flows by bringing these partners closer to each other. Such activity, however, has remained largely unknown.

With Triple Helix, we refer to a desired model of collaboration in knowledge creation and commercialization between universities (other higher educational institutes-HEI), business, and government. Accordingly, the three actors adopt some of each other's activities and integrate to a certain extent while they set agenda's for future (regional) development with shared aims and strategy (Etzkowitz and Leydesdorff 2000; Etzkowitz 2008). In the past years, developments in innovation models, particularly the need for including 'user groups' in knowledge commercialization, made the Triple Helix evolve into a Quadruple Helix (Leydesdorff and Etzkowitz 2003). In many knowledge economies, 
however, the model does not work satisfactory due to the influence of various barriers between the actors involved (Geuna and Muscio 2009; Bruneel et al. 2010; van Geenhuizen 2013), mainly divided into two "realms," the research community and the business community separated by what has been named the "innovation gap" (e.g., Dasgupta and David 1994; Kaufmann and Tödtling 2001; Furman et al. 2002).

Barriers preventing knowledge flow and collaboration may be related to task conflicts and relationship conflicts (Ranga and Etzkowitz 2013). Common task conflicts originate from diverse aims in knowledge production and related time horizons. Universities use time horizons of four years (PhD research) and aim at a scientific output and recognition among peers in the first place, while the business world avoids starting research or ends it if no commercial opportunities are perceived. Besides, they employ different attitudes on disclosure of research results (IP) (Bruneel et al. 2010). Relationship conflicts are stronger connected to personal affinity and preferences. Thus, a weak affinity of university researchers with applied studies and with the market may act as a main barrier causing delay or failure of commercialization (van Geenhuizen 2013). The presence of manifold barriers calls for intermediation or mediator roles.

University spin-offs (USOs) are conceptualized in this study as a specific class of independently established technology-based start-ups that bring university knowledge to market, mostly founded by university graduates or staff members (Pirnay et al. 2003). USOs are relatively poor in resources and lack skills beyond their technology field, due to their young age and one-sided education (Vohora et al. 2004; van Geenhuizen and Soetanto 2009; Soetanto and van Geenhuizen 2015), but they improve this situation by connecting themselves with other Triple/Quadruple Helix actors, like large and small companies, public authorities, financial investors, etc. The activity of bringing inventions and other solutions created at university to market or societal use, could be seen as a passive intermediary role. However, in their networks, USOs may actively perform a mediator role while connecting themselves with other Triple Helix actors and affect not only the knowledge being commercialized but also the behavior of networks and actors involved. In this line of thinking, Doganova (2013) distinguishes between the role of spin-off firms in transformation and transfer of knowledge between different worlds, university and business, and the mediator role for a variety of actors, like researchers, users, customers, investors, etc., thereby also affecting and sometimes even transforming the networks and network participants. The latter tends to be associated with exploration activity and collective learning; hence, a diversity of actors is seen as critically important. While much attention has been paid to intermediaries like university transfer offices, knowledge intensive service firms (KIBS), knowledge brokers and knowledge platforms as living labs, USOs have remained out of this range (Howells 2006; Todeva, 2013; Meyer and Kearnes 2013; Schlierf and Meyer 2013; van Geenhuizen 2014) with the exception of Doganova (2013).

Against this backdrop the following research questions are addressed: What is the pattern of diversity in partners connected in spin-off networks? To what extent are spin-offs faced with different potentials for a role as Triple Helix mediator and which factors enhance the shaping of partner diversity serving this role? The study is confined to knowledge networks that support commercialization of knowledge created at university while it excludes policy networks. Accordingly, the paper first explores the broader concept of intermediary in Triple Helix interaction and then moves to a mediator role 
performed by spin-offs. Next, the attention turns to the empirical study on the network relationships of USOs in terms of potential mediator activity, with a focus on partner diversity. We estimate various influences on the shaping of partner diversity and illustrate the main trends using two case studies displaying different mediator roles. The paper concludes with a summary, policy relevance and a brief indication of future research paths.

\section{Spin-offs as mediators}

\section{A mediator role in innovation systems}

Influence of various barriers between the actors in Triple/Quadruple Helix networks can result in unsatisfactory flow of knowledge and commercialization results (Geuna and Muscio 2009; Bruneel et al. 2010; van Geenhuizen 2013). Intermediary organizations can alleviate bottlenecks and provide a good flow of knowledge between different "realms" within the innovation system by providing value-added activities/services to individual actors. This may include communication and the facilitation of promotion, searching, learning, negotiation and decision-making, thereby reducing costs made by individual actors involved (Howells 2006; Meyer and Kearnes 2013; Todeva 2013). Some intermediation models include the support of outward flow to a range of recipients, while other models are concerned with specific networking between two or more partners. The broad set of activities and models of intermediation matches with Howells' definition of an intermediary as an organization or body that acts as an agent or broker in any aspect of the innovation process between two or more parties (Howells 2006: 720).

With regard to position in the system, intermediaries might locate in-house at one of the actors or outside, somewhere in-between and independent, as a genuine third party. Such different positions may influence the intermediation power. In this context, most USOs can be considered as relatively independent parties, partly in (close) relationships with their mother organization, the university. Further, aside from permanent intermediaries we observe the rise of intermediary organizations that are temporary, often created as "centers" in which different actors in research and policy collaborate in enhancing a new technology or application.

Spin-off firms are not established with the aim to "connect university with industry," "connect firms to each other" or to contribute to "the formation of academy-industrygovernment relationships" (Howells 2006; Metcalfe 2005; Kotha et al. 2013). Nevertheless, they act in moving and transforming new knowledge to the market, which is the "traditional" idea of knowledge transfer (Howells 2006). However, more recently attention has been attracted by a related but different activity and that is the role of mediator in connecting different Triple/Quadruple Helix actors, inserting strangers (outsiders) into the networks, while dealing with uncertainty and creating collective learning and exploration (Doganova 2013). Within a range of different intermediary activities, we focus on the role of USOs as mediator, in nurturing Triple/Quadruple Helix links, bringing partners closer together, enhance collaborative learning and eventually transform the networks.

In general, learning in innovation systems is cumulative, interactive and pathdependent, and as a result, partners tend to draw on knowledge acquired in the past or being close to their own knowledge base (Cohen and Levinthal 1990). Such a situation provides opportunities in learning but also sets clear limits due to small diversity. If 
extending networks with "strangers" however, different "distances" between them and existing network partners may act as obstacles including cultural and scientific aspects (Nooteboom 2009). USOs may change such situations through a mediator role which often brings implicit mechanisms of bridging distances in combining different capabilities and social construction of learning processes (Amin and Cohendet 2000) thereby making diversity in partners as an important attribute of the networks. Mediators not only transform the knowledge that they move toward the market, but also the social and regional "spaces" in which they circulate and the entities that are involved, such as Triple/Quadruple Helix actors (Doganova 2013). In the pragmatic approach of this paper, we perceive the following mediator roles inhibiting increasing strength: (1) connecting between partners to access to resources, such as knowledge and investment capital, (2) collaborative learning, like co-creation and co-testing, and (3) transforming existing network positions and network partners (Williams 2002; Meyer and Kearnes 2013).

\section{Need for diversity}

A certain level of partner diversity seems necessary to connect and bring together a meaningful set of partner in a mediating role. In designing a simplified model, we use two angles in understanding partner diversity, the one of entrepreneurial orientation and the one of resources/capabilities. First, spin-offs-as firms-have different entrepreneurial orientations (Lumpkin and Dess 1996), for example, in terms of level of innovativeness (risk-taking) i.e., being a first mover or (fast) follower (Mohr et al. 2010), and in terms of envisaged firm size and global position. As first movers are surrounded by a great deal of uncertainty, they have to be able to scan a wide range of external circumstances, using various individuals and groups (Mohr et al. 2010), different from firms that have adopted another strategy, like cost reduction. Secondly, the industry sector, broadly distinguished in science-based activity and market-based activity, is also seen as playing a role in network diversity (Tidd et al. 2005; Jensen et al. 2007). Most of the science-based firms operate in rapidly changing environments where more knowledge and learning from leading universities, financial institutes, public authorities, large firms, etc. are needed for bringing inventions to market and survive (Mohr et al. 2010). By contrast, non-science-based firms are mainly involved in experience-related and problem-related learning (Jensen et al. 2007). As their learning mostly takes place "on the job" in close interaction with users/customers, they may need relations that are more limited in diversity. Further, the establishment of networks requires a set of already owned resources and capabilities. That is why resources/capabilities at start of the spin-off are important, for example, these influence the receptivity to relevant knowledge and partners and the ability to connect with them. Accordingly, we also consider various capability factors that are specific for spin-offs being young start-ups, i.e., size of the founding team, and education and pre-start experience, knowing that there are contradictory trends in the literature on the outcome, positive or negative (Escribano et al. 2009; Colombo and Grilli 2010; Lee et al. 2010; Robbins and Judge 2011). And finally, we also include control factors. These are the region of establishment of the spin-off, regarding remoteness and economic specialization, influencing diversity in available partners in the region (Soetanto and van Geenhuizen 2009), 
degree of competition in the market, urging needs for different diversity in partners, and the size/age of the spin-offs, which connect with contradictory trends, like increasing resources in networking versus decreasing needs due to internalization of missing resources, potentially reducing the role of mediator.

\section{Empirical study}

Methodological aspects

Data are collected involving two universities in Europe, Delft University of Technology (TU Delft) in Delft, the Netherlands, and the National Technical University of Norway (NTNU) in Trondheim. These exemplify two different regions and incubators, Trondheim, as a remote region with a small specialized economy and an incubator with diverse stakeholder involvement (potentially as compensation) and Delft, as a core metropolitan region, with a larger and more diversified economy and single stakeholder involvement in the incubator at the time of the survey (Soetanto and van Geenhuizen 2009). In more detail, Delft as part of Randstad Netherlands faces a relatively strong presence of all Triple/Quadruple Helix actors in the region e.g., TU Delft and two general universities within $30 \mathrm{~km}$ of Delft, as well as institutes of applied research and many multinationals and European headquarters in the area. Trondheim clearly faces a weaker presence of small and large industries and corporate headquarters. The two countries involved, the Netherlands and Norway, share a similar, somewhat risk-avoiding, entrepreneurship culture (GEM 2010) and act as "innovation followers" according to main European Innovation Scoreboard indicators (ProInno Europe 2011). According to this pattern, we mainly measure differences between the Delft and Trondheim region in presence of diverse partners and control for this difference in our model estimation of network diversity ("Partner diversity and influences" section).

Data on 105 spin-off firms were collected in 2006/2007. The selection of spin-off firms took place using the criteria of existing in 2006 and being no older than 10 years. All firms in the population (150) were approached for the interview, with an overall response rate of $70 \%$ (105 firms). Note that excluding non-survivors might have been a source of bias; however, it appeared that mortality rates among university spin-off firms are relatively low. Mustar et al. (2008) in a European study suggest that $75 \%$ survived after 6 years, whereas local experts in Delft even suggest an $85 \%$ survival rate (personal communication). This situation made us believe that representativeness of the sample for the population at the two universities is not a major concern. The face-to-face interview, using a semi-structured questionnaire, took 50 to $90 \mathrm{~min}$, to obtain a good impression of the networks addressed at the firm's level and of the socio-economic background of the partners. Several pilot interviews were conducted first, with the finding that the respondents would be better able to provide precise details about important networks partners if the maximum size of the networks is set at five persons. The network, as it was measured, is also limited to the ego-network. We are also dealing with early networks, meaning that most probably the spin-offs are in a process of moving away from small social circle-based networks (partners at university from pre-start times, small incubator firms, friends) to including new arm's length relations like with (launching) customers and suppliers, and potentially adopting a stronger mediator role (Hite and Hesterley 2001). 
Partner diversity is measured using the different social and economic circles of partners, particularly Triple/Quadruple Helix, including their location (local/regional and national) which may be relevant if the region is poor in diversity. Partner diversity is calculated as the product of socio-economic background diversity and local/regional diversity, as follows:

$$
\operatorname{Div}=H s\left(1+\frac{E I}{2}\right)
$$

and

$$
H s=1-\sum_{k=1}^{8}\left(\frac{a_{k}}{N}\right)^{2}
$$

where $a_{k}$ is the number of partners with a different socio-economic background, and where $k=1$ (large business), 2 (university), 3 (small business), 4 (government), 5 (family or friends), 6 (financial investor), 7 (lead customer), and 8 (others). $N$ is the total number of partners with whom a spin-off interacts (one type for each partner), and a higher value indicates a higher level of socio-economic background difference (min 0; max 1). Note that a partner could be assigned to only one partner type (main identity). In addition, partner location is calculated as:

$$
E I=\frac{E_{p}-I_{p}}{E_{p}+I_{p}}
$$

where $E_{p}$ is the number of external, non-local, partners, at more than 60 min by car, and $I_{p}$ is the number of local partners $\left(E_{p}+I_{p}=N\right)$. A high value indicates a relatively strong external orientation.

Descriptive statistics of all model variables are shown in Table 1.

\section{Partner diversity and influences}

This section focuses on the type of network partners, from the viewpoint that relatively high partner diversity enhances the performance of spin-offs as mediators. On average, the socio-economic partner diversity reaches the value of 0.35 with a maximum of 0.9 (Table 1). This tends to be somewhat low which is also witnessed when simply counting the number of different partners per spin-off, with most of them (60\%) having not more than two different partners (Table 2). However, one third (33\%) employs three to five different partner types and one quarter $(26 \%)$ inserted a majority of strangers in the network while almost half ( $48 \%$ ) inserted more than one stranger in the network. For spin-offs, introducing strangers into their networks is an important step in professionalizing, moving away from relational embeddedness (friends and previous colleagues). Professionalizing networks does not only mean achieving access to resources in a "transaction cost mode" but also taking the opportunity of higher levels of learning and affecting the networks and partners involved.

In a further exploration of a mediator role, we take a closer look at the types of partners that are connected. Involvement of large firms may point to their acting as launching customer, as a partner in co-development/testing or as access to sales organization in global markets. Involvement of the government at a high level, may include regulatory issues, like responding to certification requirements, but also organization of pilots and niches in 
Table 1 Measurement and descriptive statistics

\begin{tabular}{|c|c|}
\hline \multicolumn{2}{|l|}{ Control variables } \\
\hline $\begin{array}{l}\text { City region: variable in two categories, as a dummy } \\
\text { (Trondheim }=1 \text { ) }\end{array}$ & Trondheim 42 \%; Delft 58 \% \\
\hline $\begin{array}{l}\text { Market competition: variable in two categories (many } \\
\text { competitors }=1 \text { ) }\end{array}$ & Many competitors $56 \%$; few competitors $44 \%$ \\
\hline Firm age: continuous variable & Avg. 4.9; sd 3.1; min-max 0-10 \\
\hline $\begin{array}{l}\text { Firm size: continuous variable as number of full time } \\
\text { equivalent in } 2006\end{array}$ & Avg. 7.2; sd 6.9; min-max 0.5-51 \\
\hline \multicolumn{2}{|l|}{ Capability factors } \\
\hline $\begin{array}{l}\text { Size of founding team: continuous variable as team } \\
\text { members at foundation }\end{array}$ & Avg. 2.3; sd 1.2; min-max 1-5 \\
\hline $\begin{array}{l}\text { Pre-start experience areas: continuous variable as sum of } \\
\text { types of founders' experience in various domains }\end{array}$ & Avg. 1.1; sd 0.9; min-max 0-3 \\
\hline $\begin{array}{l}\text { Education level of founding team (number of PhD): } \\
\text { continuous variable measuring the members with PhD }\end{array}$ & Avg. 0.6; sd 0.9; min-max 0-3 \\
\hline $\begin{array}{l}\text { Multidisciplinary education of founding team: variable in } \\
\text { two categories (multiple studies }=1 \text { ) }\end{array}$ & $\begin{array}{l}\text { Single technology (65.7\%); multiple studies } \\
(34.3 \%)\end{array}$ \\
\hline $\begin{array}{l}\text { Participation in training: variable in two categories, yes (1) } \\
\text { and no (0), as a dummy }\end{array}$ & Yes (31.4 \%); no (68.6 \%) \\
\hline \multicolumn{2}{|l|}{ Entrepreneurial orientation } \\
\hline $\begin{array}{l}\text { Initial growth strategy: a compound variable (size and } \\
\text { international orientation), in three categories }\end{array}$ & $\begin{array}{l}\text { Large and international (37\%); small and } \\
\text { international (53\%); small and local (10 \%) }\end{array}$ \\
\hline $\begin{array}{l}\text { Type of innovation activity: variable in two categories, } \\
\text { science-based ( } 1 \text { ) and non-science-based (0), as a dummy }\end{array}$ & Science-based: 27 \%; non-science based: $73 \%$ \\
\hline $\begin{array}{l}\text { Level of innovativeness: continuous variable derived as a } \\
\text { compound variable from R\&D expenditure, newness in } \\
\text { innovation, and patenting (based on factor analysis) }\end{array}$ & Avg. 0.1; sd 0.85; min-max -1.4 to 1.1 \\
\hline \multicolumn{2}{|l|}{ Dependent variable } \\
\hline $\begin{array}{l}\text { Diversity: continuous variable indicating social-economic } \\
\text { diversity of knowledge partners, incl. spatial orientation }\end{array}$ & Avg. 0.35; sd 0.2; min-max 0-0.9 \\
\hline
\end{tabular}

which policy makers are partners in learning and experiments. A large group of spin-offs connect only between the mother organization and a large firm, at $45 \%$, pointing to a more one-sided network. Having both large firms and higher level policy makers (government), eventually also the university, holds for $26 \%$ of the spin-offs (Table 3). This result suggests a potentially important mediator role for part of the spin-offs.

The above trends can be summarized as follows. Socio-economic partner diversity tends to be somewhat low; however, one third of the spin-offs (33\%) employ three to five different partners and an almost similar amount connects with large firms as well as governments, which can be seen as a large potential for diversified learning and

Table 2 Relation between partner diversity and partners as strangers/outsiders (percentage share in italic)

\begin{tabular}{llllll}
\hline $\begin{array}{l}\text { Number of different } \\
\text { partners (diversity) }\end{array}$ & \multicolumn{3}{l}{ No. stranger relationships } & Total \\
\cline { 2 - 5 } & 0 & 1 & $2 / 3$ & 4 & \\
\hline 1 & 6 & 1 & 0 & 0 & $7(6.7)$ \\
2 & 20 & 19 & 15 & 9 & $63(60.0)$ \\
3 & 5 & 2 & 6 & 11 & $24(22.8)$ \\
$4 / 5$ & 1 & 1 & 2 & 7 & $11(10.5)$ \\
Totals & $32(30.5)$ & $23(21.9)$ & $23(21.9)$ & $27(25.7)$ & $105(100.0)$ \\
\hline
\end{tabular}

Pearson $\operatorname{chi}^{2}(16)=31.154 p=0.000$ 
Table 3 Combinations of partner types per spin-off

\begin{tabular}{lll}
\hline Combinations of partner types & Frequency & Percentage \\
\hline University + large firm & 47 & 44.8 \\
Large firm + government & 17 & 16.2 \\
University + government & 17 & 16.2 \\
University + large firm + government & 11 & 10.4 \\
Single partner or merely similar partners & 13 & 12.4 \\
Total number of spin-offs & 105 & 100 \\
\hline
\end{tabular}

connecting by spin-offs in a mediator role. What adds to this is the trend that almost half of the spin-offs have shaped their networks by inserting two or more strangers, going partially hand-in-hand with employing a larger partner diversity (three or more), as witnessed by $25 \%$. Overall, a mediator role seems not realistic for all kinds of university spin-off firms, but there is a minority of roughly 25 to $35 \%$, dependent on the network characteristic taken into account that have adopted such a role.

We now explore the rise of partner diversity at a more abstract level, using regression analysis. Including all model variables produces an $R^{2}$ of 0.49 in a significant model (Table 4). With regard to the control variables, two of them produce significant results. The city region variable, in that spin-offs in Trondheim tend to have more diverse partners in their relations, partially as "compensation" outside the region, with oil companies, venture funds, and instrumentation manufacturers, along with the local university, while a larger firm size (employees) tends to produce a higher network diversity. With regard to capability factors, we observe the following trends. First, a

Table 4 Regression analysis of partner diversity

\begin{tabular}{ll}
\hline & $B$ coefficient (standard error) \\
\hline Control variables & \\
City region (Trondheim =1) & $0.33(0.17)^{*}$ \\
Market competition & $0.10(0.17)$ \\
Firm size (at time of survey) (fte) & $0.72(0.11)^{* * *}$ \\
Capability factors (founding team) & \\
Size of founding team & $-0.64(0.24)^{* * *}$ \\
Pre-start experience (domains) & $0.19(0.10)^{* *}$ \\
Education level & $0.01(0.14)$ \\
Multidisciplinary education & $0.43(0.18)^{* *}$ \\
Participation in training & $0.45(0.36)$ \\
Entrepreneurial orientation & \\
Initial growth strategy & $0.04(0.09)$ \\
Innovation activity type (science-based $=1)$ & $0.30(0.21)$ \\
Level of innovativeness & $0.21(0.11)^{*}$ \\
$N$ & 105 \\
$F$ & $7.99^{* * *}$ \\
$R^{2}$ & 0.49 \\
Root MSE & 0.76
\end{tabular}

Source: Adapted from Taheri (2013)

${ }^{*} p<0.1$

${ }^{* *} p<0.05$

${ }^{* * *} p<0.01$ 
negative sign of the beta-coefficient for size of the founding team. Apparently, with more founders the need to access different external partners tends to decline because the knowledge covering different areas can be developed internally. A second trend is a positive influence of pre-start experience as number of experience domains. Apparently, a greater experience of founders in different areas stimulates a larger diversity in partners. The same holds for multidisciplinary education, as assumed. With regard to entrepreneurial orientation, an emphasis on strong innovation goals, as indicated by science-based innovation activity (a positive sign and "almost" significant) and level of innovativeness, tends to increase diversity, indicating collaboration and transforming of networks.

We may conclude that an important driver of partner diversity is the level of innovativeness and this is facilitated by richness in experience and education. Accordingly, these factors tend to enhance a potential role of spin-offs as mediators, which also holds true for size of the spin-offs after some years of existence.

\section{Actual roles of mediator}

As a final step, we selected two case studies of spin-off firms to explore the actual roles of mediator. Both firms originated from Delft University of Technology. Spin-off A (established in 2005) has built a highly diverse network of important Triple/Quadruple Helix players in the development of an improved charging system for electric vehicles (EVs) (shorter charging time of batteries). An active interaction between partners took place in several pilot studies to test the charging system, namely at the national Airport Amsterdam and in selected cities in the Netherlands (collaboration role). The networks since 2006 included five different partner types: car manufacturer (Japan), electricity providing company, battery manufacturer, airport and municipal authority (pilot testing and learning niches), and a multinational energy/electrical installations company as a potential customer. Several partners did not know each other before. We assume that partners in the pilot testing have been relatively close to each other because they were interacting and learning on the spot on how the charging system worked. Further, the spin-off-in search of investment capital-also connected with a Taiwanese manufacturing company and a green venture capital firm in Canada (Vancouver), thereby increasing international credibility of network partners. Important conclusions were drawn after the pilots, with respect to car industry, namely, that fast-charging is only possible with a charger that is not in the car and other electrical vehicles. The charger can be mass-produced only as a separate device to realize market growth, which appeared as an important message to German and American car industry. Also, the later pilots stimulated thinking about establishing a network of fastcharging stations over the Netherlands, thereby enlarging the network into an important direction (Lubbers, 2015). Accordingly, the mediator role was not only dealing with access to resources and collaborative learning but it also influenced positions in the car manufacturing industry and systems of fast-charging stations. Factors underlying the required diversity in the networks, encompassed both pre-start experience and multidisciplinary education in the founding team, the last including electrical energy and industrial design. Probably more important, but not visible in our model estimation, was the attraction of an experienced CEO (in 2009) giving an additional boost to networking. Further, the entrepreneurial orientation was clearly dominated by the desire of being the first mover and the wish to become a global actor. As a final remark, following the 
positive pilot projects, the spin-off appeared not to be able to build a global sales organization on its own, reason why it joined the large multinational with which it was already collaborating.

Spin-off B (established in 2006) is active in innovative eye-diagnostics and introduced its highly innovative product-laser-based retinal imaging equipment-in 2012. The innovative element included a patient-friendly measurement (no eye drops required) and ease of mobile use, which made it attractive for eye-care in rural areas in developing countries. Like the previous spin-off, it established a highly diverse network, including venture capitalists (partly from abroad), medical hospitals, a large Dutch MNC, and more recently a Japanese MNC head quartered in the Netherlands (sales in Europe). There were no protective niches involved, probably meaning that most partners were not directly linked to each other in a testing situation and the mediator role was somewhat weaker compared to the first case study. In the background to the shaping of the network, we observe a single founder and pre-start experience in manufacturing and consultancy, both tending to contribute to building a diversified network. And again, the attraction of an experienced CEO in 2010 has boosted the spin-off's development. In rolling out its sales organization today, the spin-off has remained independent but it searches for investment capital, thereby influencing learning in a limited part of the network and in a loose manner.

We conclude in a preliminary way that the Triple/Quadruple Helix networks observed serve three main purposes, collaborative development and testing of the invention in practice, providing investment capital and sales networks and transforming existing network positions and network partners. Only the first case connected to "new worlds" by influencing positions in the car industry and opening innovative thinking about distribution networks. We may assume accordingly that collaborative learning in testing of the invention in practice produces the most diverse and tightest networks and accordingly brings key Triple/Quadruple Helix partners relatively close to each other, thereby changing the network and network actors in the "strongest" mediator role.

The question can be posed as how long such network features will remain after the testing and concomitant learning have come to an end. If the spin-off intends to remain innovative, each time bringing new (related) inventions to market, a mediator role can be continued eventually with slightly different partners. However, if the firm intends to develop for mass markets for its sole invention, the mediator roles may be temporary for this firm.

\section{Conclusion}

In transforming new knowledge to products or services in the market, spin-off firms may perform a mediator role, which is explored in this paper. Accordingly, three different roles of spin-offs in connecting with partners to enable access to resources, collaborative learning, and transforming networks and network partners are distinguished. Such roles are often not intended and therefore somewhat hidden. We contributed to understanding of the mediator role by focusing on the required diversity in exploring a simplified causal model and by performing case study analysis. In our sample of 105 firms, partner diversity tended to be somewhat low; however, a quarter to one third of the spin-offs employed three to five different partners and an almost similar share connected with large firms as 
well as governments and included mainly strangers, which can be seen as relatively large potentials in a mediator role. In addition, we found the level of innovativeness to be an important driver of diversity, with richness in education and pre-start experience of the founders as important enabling factors. The two case studies, both employing strong partner diversity, pointed to different mediator roles, those serving collaborative learning in testing in practice, and those providing access to investment capital and sales organization, of which the first one tended to bring different Triple/Quadruple Helix actors most closely together and provided ground for transformation of the network and network actors.

The previous results have some policy relevance, as collective learning and network transformation are important ingredients in a quicker market introduction of innovations (like in medical and sustainability areas) and in an overall better performing innovation system. Accordingly, managers of incubators and early entrepreneurs could be advised to avoid composing a large founding team, but include members that own pre-start experience as well as a different disciplinary background. Next, entrepreneurs would be advised to be active in organizing various testing under different circumstances and diverse partner involvement to develop critical and provocative ideas.

This study has also some limitations. Firstly, the generalizability of the results seems limited to technical universities in coastal Northwest Europe, due to specificities of the regions involved, with a relatively strong presence of energy and maritime activities and coastal civil works. Secondly, given the rather small sample, partner diversity was explored by looking at a limited number of factors. Increasing the model parameters could further improve the results, for example, with an indicator that measures communication and negotiation abilities or the presence of an external CEO. Thirdly, and most importantly, direct measurement of the mediator role could take place using a larger sample, in-stead of modeling partner diversity, as one of the requirements. This would include picturing the mediator activity itself and the precise actions of the spinoffs, finding valid indicators for structuring processes of collective learning and network change, like suggested some years ago for biotechnology (Shan et al. 1994; Rothaermel 2001). Measuring activities and impacts of any intermediary organization in a systematic way, however, remains a challenge as many of them work mainly indirectly and not always on purpose (Howells, 2006; Sapsed et al., 2007; Suvinen et al. 2015). Indeed, there is a whole research field ahead of us.

\section{Additional file}

Additional file 1: Translation of the abstract into Arabic. (PDF $306 \mathrm{~kb}$ )

Competing interests

The authors declare that they have no competing interests.

Authors' contributions

MVG guided the overall study by providing the theme of mediator (and conceptualization) and did part of the interpretation of quantitative results. QY carried out main parts of the quantitative analysis and part of interpretation. MT had inputs into the interpretation part and in finalizing the manuscript. All authors read and approved the final manuscript.

Author details

${ }^{1}$ Faculty of Technology, Policy and Management, Delft University of Technology, Jaffalaan 5, 2628 BX Delft, The Netherlands. ${ }^{2}$ China Europe International Business School, Shanghai, China. 
Received: 22 September 2015 Accepted: 8 March 2016

Published online: 01 April 2016

\section{References}

Amin A, Cohendet P (2000) Organizational learning and governance through embedded practices. J Manag Gov 4:93-116 Bruneel J, d'Este P, Salter A (2010) Investigating the factors that diminish the barriers to university-industry collaboration. Res Policy 39:858-868

Cohen WM, Levinthal DA (1990) Absorptive capacity: a new perspective on learning and innovation. Adm Sci Q $35: 128-152$

Colombo MG, Grilli L (2010) On growth drivers of high-tech start-ups: exploring the role of founders' human capital and venture capital. J Bus Ventur 26(6):610-626

Dasgupta P, David PA (1994) Toward a new economics of science. Res Policy 23:487-521

Doganova L (2013) Transfer and exploration: two models of science-industry intermediation. Sci Public Policy 40:442-452

EC (European Commission) (2014) The future of Europe is science. A report of the Presidents' Science and Technology Advisory Council (STAC). European Commission, Brussels

Escribano A, Fosfuri A, Tribo J (2009) Managing external knowledge flows: the moderating role of absorptive capacity. Res Policy 38(1):96-105

Etzkowitz H (2008) The Triple Helix: university-industry-government innovation in action. Routledge, London

Etzkowitz H, Leydesdorff L (2000) The dynamics of innovation: from National systems and 'mode 2' to a triple helix of university-industry-government relations. Res Policy 29:109-123

Furman JL, Porter ME, Stern S (2002) The determinants of national innovative capacity. Res Policy 31:899-933

GEM 2010: http://www.gemconsortium.org/docs/266/gem-2010-global-report Accessed December 2014

Geuna A, Muscio A (2009) The governance of university knowledge transfer: a critical review of the literature. Minerva 47(1):93-114

Hite JM, Hesterley WS (2001) The evolution of firm networks: from emergence to early growth of the firm. Strateg Manag J 22(3):275-286

Howells J (2006) Intermediation and the role of intermediaries in innovation. Res Policy 35(5):715-728

Jensen MB, Johnson B, Lorenz E, Lundvall BA (2007) Forms of knowledge and modes of innovation. Res Policy 36:680-693

Kaufmann A, Tödtling F (2001) Science-industry interaction in the process of innovation: the importance of boundarycrossing between systems. Res Policy 30:791-804

Kotha R, George G, Srikanth K (2013) Bridging the mutual knowledge gap: coordination and the commercialization of radical science. Acad Manage J 56(2):498-524

Lee S, Park G, Yoon B, Park J (2010) Open innovation in SMEs, an intermediated network model. Res Policy 39(2):290-300

Leydesdorff L, Etzkowitz H (2003) Can "the public" be considered as a Fourth Helix in university-industry-government relations? Report of the Fourth Triple Helix conference. Sci Public Policy 30(1):55-61

Lubbers B (2015) The FastNed story part I\&Il. Boekenbent, Barneveld

Lumpkin GT, Dess G (1996) Clarifying the entrepreneurial orientation construct and linking it to performance. Acad Manag Rev 21(1):135-172

Metcalfe AS (2005) Towards a theory of intermediating organisations: agency between the academy, industry and government. The Triple Helix 5 Conference, Turin

Meyer M, Kearnes M (2013) Introduction to special issue: intermediaries between science, policy and the market. Sci Public Policy 40(4):423-429

Mohr J, Sengupta S, Slater S (2010) Marketing of high-technology products and innovations. Pearson, New Jersey

Mustar P, Wright M, Clarysse B (2008) University spin-off firms: lessons from ten years of experience in Europe. Sci Public Policy 35(2):67-80

Nooteboom B (2009) A cognitive theory of the firm; learning, governance and dynamic capabilities. Edward Elgar, Cheltenham

Pirnay F, Surlemont B, Nlemvo F (2003) Toward a typology of university spin-offs. Small Bus Econ 21(4):355-369

Pro-Inno Europe (2011) European Innovation Scoreboard 2011. European Union, Brussels. https://ec.europa.eu/research/ innovation-union/pdf/iu-scoreboard-2010_en.pdf Accessed December 2014

Ranga M, Etzkowitz H (2013) Triple Helix systems: an analytical framework for innovation policy and practice in the knowledge society. Ind High Educ 27(3):237-262

Robbins SP, Judge TA (2011) Organizational behaviour. Prentice Hall, New Jersey

Rothaermel FT (2001) Complementary assets, strategic alliances, and the incumbent's advantage: an empirical study of industry and firm effects in the biopharmaceutical industry. Res Policy 30:1235-1251

Sapsed J, Grantham A, Defillippi R (2007) A bridge over troubled waters: bridging organisations and entrepreneurial opportunities in emerging sectors. Res Policy 31(3):303-328

Schlierf K, Meyer M (2013) Situating knowledge intermediation: insights from science shops and knowledge brokers. Sci Public Policy 40(4):430-441

Shan W, Walker G, Kogut B (1994) Inter-firm cooperation and start-up innovation in the biotechnology industry. Strateg Manag J 15:387-94

Soetanto DP, van Geenhuizen M (2009) Social networks and competitive growth of university spin-off firms: a tale of two contrasting cities. J Econ Soc Geogr 100(2):198-209

Soetanto DP, van Geenhuizen M (2015) Getting the right balance: university networks' influence on spin-offs' attraction of funding for innovation. Technovation 36:26-38

Suvinen N, Konttinen J, Nieminen M (2015) How necessary are intermediary organizations in the commercialization of research? Eur Plann Stud 18(9):1365-1389

Taheri M (2013) From mind to market at university. How diversity in knowledge networks makes a difference. TU Delft, Dissertation 
Tidd J, Bessant J, Pavitt K (2005) Managing innovation. Wiley, Sussex

Todeva E (2013) Governance of innovation and intermediation in Triple Helix interactions. Ind High Educ 27(4):263-278

van Geenhuizen M (2013) From ivory tower to living lab: accelerating the use of university knowledge. Environ Plann C: Gov Policy 31:1115-1132

van Geenhuizen M (2014) Critical factors in health innovation in cities: from ivory tower to living lab. Int J Glob Environ Issues 13(2):258-280

van Geenhuizen M, Soetanto D (2009) Academic spin-offs at different ages: a case study in search of obstacles to growth. Technovation 29(10):671-681

Vohora A, Wright M, Lockett A (2004) Critical junctures in the development of university high-tech spin-out companies. Res Policy 33(1):147-175

Williams P (2002) The competent boundary spanner. Public Adm 80(1):103-124

Submit your manuscript to a SpringerOpen ${ }^{\mathcal{O}}$ journal and benefit from:

- Convenient online submission

- Rigorous peer review

- Immediate publication on acceptance

- Open access: articles freely available online

- High visibility within the field

- Retaining the copyright to your article

Submit your next manuscript at $\boldsymbol{s p r i n g e r o p e n . c o m ~}$ 